\title{
GONAD MATURITY LEVEL OF VARUNA LITTERATA IN THE KALIMIRENG RIVER ESTUARY OF MANYAR GRESIK DISTRICT, EAST JAVA, INDONESIA
}

\author{
Fariedah Fani*, Widodo Maheno Sri, Yuwanita Rani \\ Study Program of Aquaculture, Department of Fisheries Resources Utilization, \\ Fisheries and Marine Science Faculty, University of Brawijaya, Malang, Indonesia \\ *E-mail: fanifariedah@ub.ac.id
}

\begin{abstract}
Varuna litterata is one of the crabs belonging to the genus Varuna and in the family Varunidae. The capture of $V$. litterata is used to provide a source of animal protein for the surrounding community, in addition to its PUFA and chromium content which are beneficial for health. This study aimed to determine the level of gonad maturity of $V$. litterata. The study was conducted by taking samples at the mouth of the Kalimireng River once every two weeks at high tide from June to August 2021 with fishing gear in the form of a plugged net that was plugged in randomly. The results showed that the carapace width in males ranged from 20 to $42 \mathrm{~mm}$, while the carapace width in females ranged from 23 to $39 \mathrm{~mm}$. The sex ratio in this study was 2.05 . The results of maturity gonad observations showed that there was no $V$. litterata that was undergoing gonad maturity at stage IV. It is still necessary to see the relationship between carapace width, claw length and gonad maturity, and it is necessary to observe gonadal changes related to gonadal maturity.
\end{abstract}

\section{KEY WORDS}

V. litterata, gonad maturity, sex ratio.

$V$. litterata in addition to having an important role in supporting the balance of the ecosystem, is also captured by the community as a source of animal protein. Crabs from this family are known to be able to live well in fresh water and sea water. Currently, varunid crabs have commercial, scientific and medical value, including Eriocheir sinensis, E. japonica, Platyeriocheir Formosa, Varuna litterata, V. yui and Metaplax gocogensis. Although V. litterata and $V$. yui are not as popular as Eriocheirs, they still have high selling points in East and Southeast Asian countries (Ngan Kee, 2006).

$V$. litterata apart from being a source of animal protein also contains several unsaturated fatty acids such as PUFA (Polyunsaturated Fatty Acid) which can reduce the incidence of coronary heart disease, besides that $V$. litterata is also rich in chromium which can help insulin to metabolize sugar so it is good for consumption for patients with hyperglycemia (Das et al., 2015).

$V$. litterata, which belongs to the family Varunidae, is one of the crabs that has been found in Indonesia, precisely in Halmahera, Maluku (Kali Mahapatra et al., 2017), Gorontalo in the northern part of Sulawesi and the Special Region of Yogyakarta in the central part of Java (Eprilurahman \& Tejo Baskoro, 2015; Lapolo et al., 2018), and in 2020 its presence was reported on the east coast of East Java, precisely in the Meru Betiri National Park, East Java (Susilo et al., 2020). The presence of this species in the in the waters of Gresik or in the Madura strait has never been reported.

Currently, the existence of $V$. litterata is being threatened due to the emergence of a new industrial area along the Kalimireng River Estuary, Manyar Gresik District, East Java. However, on the other hand, efforts to support the domestication of $V$. litterata have not been carried out. Based on data (IUCN Red List, 2020) V. litterata in Southeast Asia, including fish species that have not been evaluated (not evaluated), this status is suspected to cause a decrease in the population of $V$. litterata because people still think that $V$. litterata is still in a safe condition.

Efforts to cultivate it are still constrained by the lack of information about the reproductive biology of $V$. litterata. This study aimed to obtain information about the 
development of gonad maturity which can then be used in the future as information or instructions for cultivation activities.

\section{MATERIALS AND METHODS OF RESEARCH}

The materials used in this study were machetes, plastic bags, raffia, scissors, $\mathrm{pH}$ meter, meter, refractometer, thermometer, GPS (Global Positioning System), compass, digital camera, stationery, shovel, label paper, permanent marker, compass. shovels and scales. The materials used are crabs, trash fish as bait. $V$. litterata is caught using fishing nets once every two weeks at high tide from June - August.

The samples of $V$. litterata obtained were separated by males and females and calculated to determine the sex ratio, then the sample was measured for carapace width and body weight was weighed. Determination of the maturity level of male and female gonads was carried out by surgery and observations were made by looking at the macroscopic characters on the gonads, in the form of size, colour, and surgery to observe morphologically on the male and female gonads. In addition, an analysis of the size frequency distribution was also carried out at each stage of gonadal development.

The environmental factors that were observed were temperature, dissolved oxygen, $\mathrm{pH}$ and substrate.

The data that has been obtained is then carried out descriptive analysis to describe the description of the phenomena found in the field.

\section{RESULTS OF STUDY}

$V$. litterata caught during the study were 157 females and 323 males, having a sex ratio of 1: 2.06. These results indicate an unbalanced comparison because the number of male individuals is more than female individuals.

The results of observations on the maturity level of the gonads are known to be at various levels of gonad maturity, namely from the maturity level of the gonads I to III, the catch of $V$. litterata has not yet shown to be at the stage of gonad maturity IV. Figures 1 and 2 show a comparison of the percentage of gonadal maturity in males and females. $V$. litterata with a carapace width of $2.0 \mathrm{~mm}$ has begun to be found with a stage I stage of gonad maturity in both males and females, and the wider the carapace the higher the level of gonad maturity at stage III.

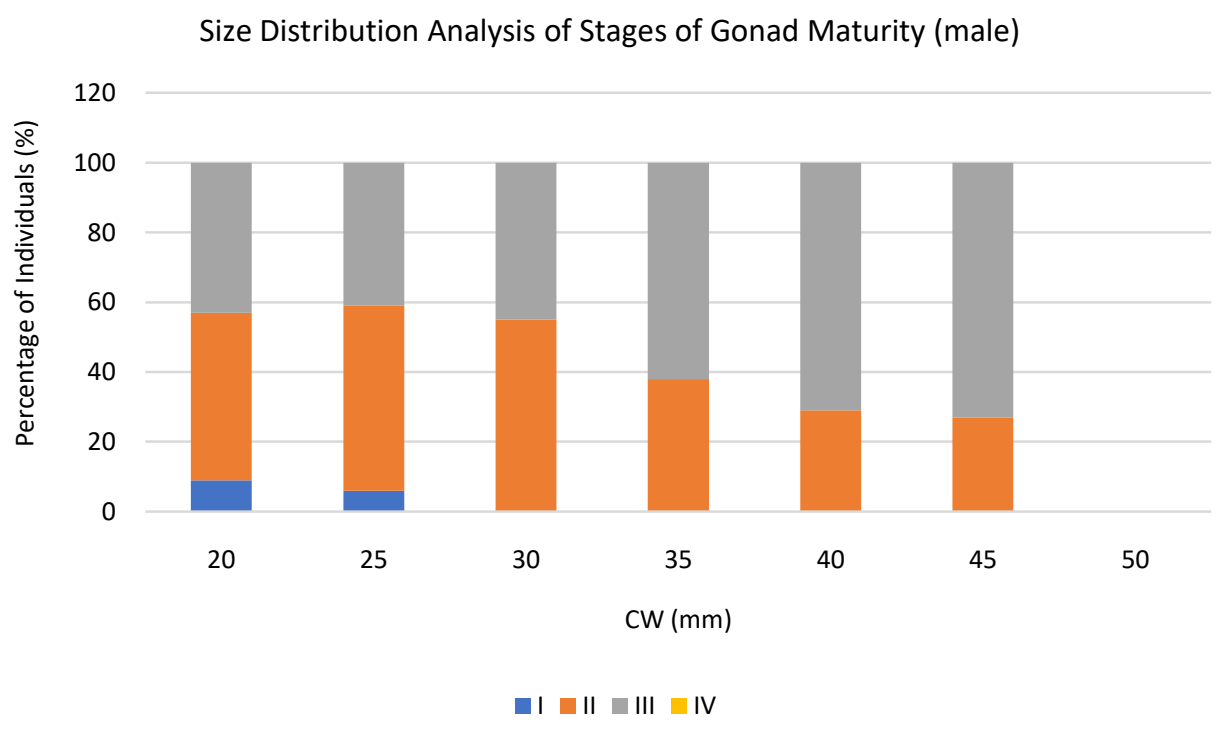

Figure $1-$ Analysis of the distribution of gonad maturity on size (carapace width $=\mathrm{mm}$ ) in male $V$. litterata 


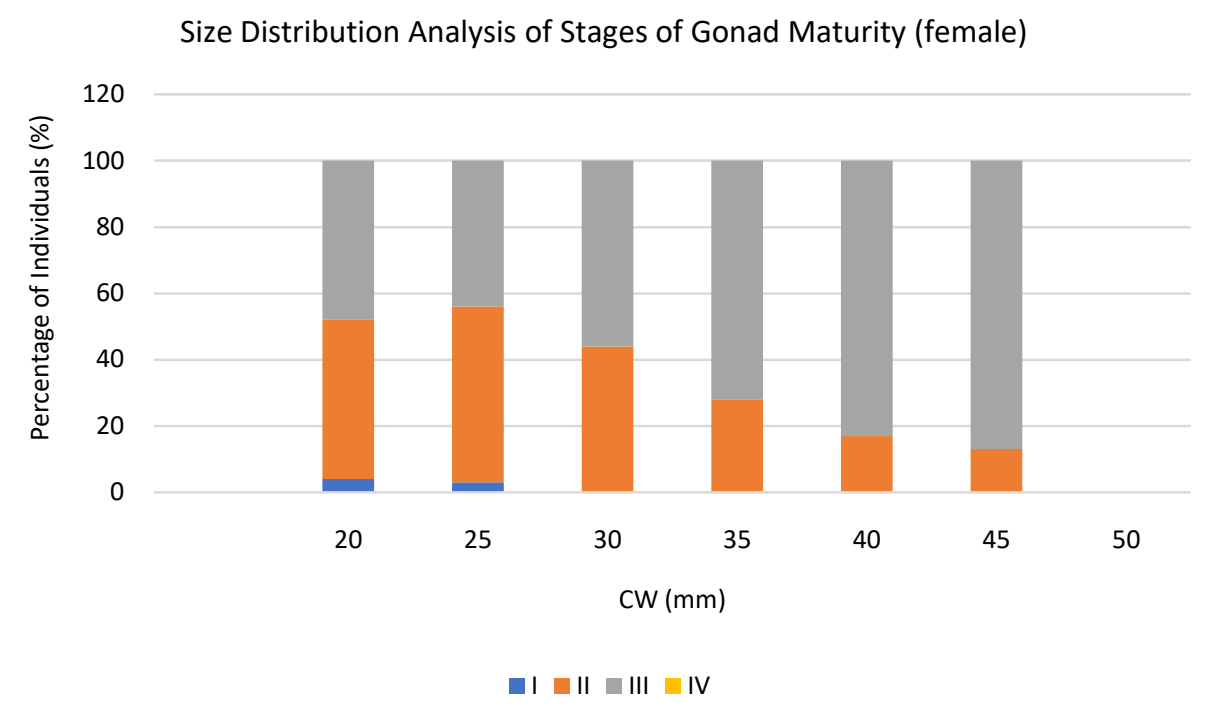

Figure $2-$ Analysis of the distribution of gonad maturity on size (carapace width $=\mathrm{mm}$ ) in female $V$. litterata

The maturity level of $V$. litterata gonads in stage III was more common in August (Figure 3). Determination of the level of gonad maturity in V. litterata refers to (Sal Moyano et al., 2011), The level of gonad maturity in stage I females is depicted as ovaries that are still transparent and the ovaries are still indistinguishable, in stage II the ovaries are still thin but can be distinguished, in stage III the ovaries have begun to look yellow due to the vitellogenesis process but the size of the ovaries still does not meet the body cavity, in stage IV the ovaries are yellow-orange and begin to fill the body cavity. The level of gonad maturity in stage 1 males is described as the testes are still thin and transparent and cannot be distinguished. In stage II the testes begin to look blurry and can be distinguished, in stage III the testes begin to look twisted, white and there are still few spermatophores, the spermatophores will be more and more in stage IV.

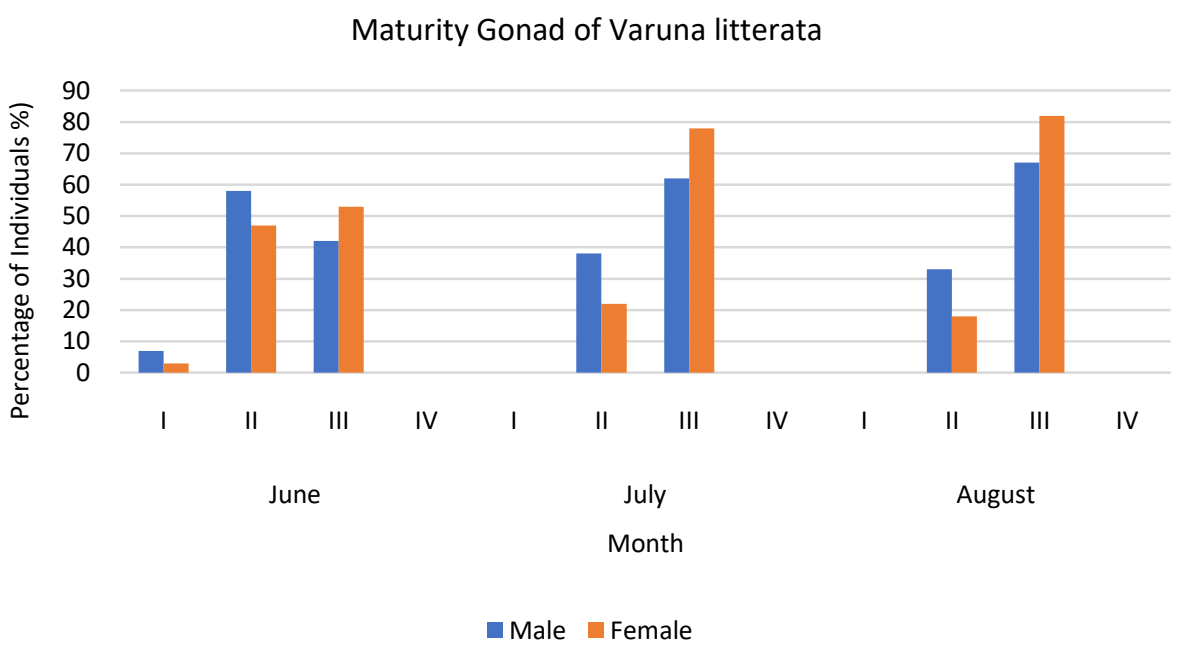

Figure 3 - Comparison of Gonad Maturity Levels of $V$. litterata in June, July, August

At the time of the research, the location where the sample was taken was still experiencing the dry season so that the salinity of the waters during the study was in the range of 20-25 ppt, $\mathrm{pH}$ ranged from 5.3-6 and dissolved oxygen was 5-6 ppm. The Kalimireng river substrate includes a muddy substrate as reported by (Lakshmi Devi \& Joseph, 2017) that $V$. litterata can be found in waters with mud, sand, and rocky substrates. 


\section{DISCUSSION OF RESULTS}

The estuary of the Kalimireng River is a mangrove area which faced to Madura strait that is developing and continues to be preserved in the Manyar District in Gresik Regency, East Java Province. Currently the area is surrounded by two industrial areas that are developing massively. The development of an industrial area that is directly adjacent to the Kalimireng river is feared to have an impact on changes in the quality of the waters in the river body which will ultimately affect the life of flora and fauna in the mangrove area of the Kalimireng river.

All the crabs caught used as samples have been examined and adapted to the identification that has been made by (Ngan Kee, 2006), that all the morphological characters possessed really match the character of $V$. litterata so there is no doubt that the samples obtained are it is true $V$. litterata.

No $V$. litterata with stage IV gonad maturity was found in the sampling results because this species is a euryhaline species that spends its adult life in lower salinity water and will return to the sea to spawn (Cumberlidge, 2016; Lakshmi Devi \& Joseph, 2017; Susilo et al., 2020; Yule et al., 2012). The location where the samples were taken was directly opposite the Java Sea, so it was very possible that after experiencing stage III gonad maturity, $V$. litterata would return to the sea to spawn. This is supported by the absence of $V$. litterata with a carapace width of less than $2.00 \mathrm{~mm}$ at the time of the study, because $V$. litterata will return to fresh water at the megalopa stage, while in the larval and zoea stages it is still in the sea.

The level of gonad maturity of $V$. litterata is not thought to be based on size, it is known from Figures 1 and 2 which illustrates that with a carapace width of $2.00 \mathrm{~mm}$, a stage III gonad maturity level with $V$. litterata gonad color is dark brown as described by (Chin-Hung, 1992) that the higher the level of gonad maturity, the ovaries will change from brown to black.

Determination of gonadal maturity level in $V$. litterata so far refers to the gonadal maturity level in crustaceans in general such as Libinia spinosa (Sal Moyano et al., 2011) and Plaguesia depressa (Guimarães et al., 2021), namely from the crustacea subphylum of the infraorder Brachyura. This is because there is still limited information about the development of gonadal maturity levels in $V$. litterata including how gonadal color changes occur in female individuals and about the presence of seminal receptacle in females as informed by (Farias et al., 2017) in Danielethus crenulatus and the presence of spermatheca. on Chinese mitten crab Eriocheir sinensis as reported by (Otto Kiel, 2012) which are both in the same family Varunidae.

\section{CONCLUSION}

The conclusion from this study was that $V$. litterata with a carapace width of $2.00 \mathrm{~mm}$ had already entered the stage of gonad maturity III in both males and females. No V. litterata was found at the stage of gonad maturity stage IV in June-August. Research still needs to be continued to determine the complete development of gonadal maturity level in $V$. litterata as well as macroscopic changes that occur during the gonadal development process.

\section{ACKNOWLEDGMENTS}

The authors express many thanks to Mr. Isharul Munir and Shobirin, as well as the POKMASWAS Kalimireng organization which has helped researchers in the research period.

\section{AUTHORS' CONTRIBUTION}

All authors have contributed to the writing of the manuscript. Contributions given by each author are as follows, Rani as a data collector, drafting the manuscript and designing images. Fani and Maheno design the concept of writing as well as determine critical discussions. All authors then discuss until the manuscript becomes the final document. 


\section{CONFLICT OF INTEREST}

The author states that there is no interest whatsoever in this research other than to study one part of the reproductive biology of $V$. litterata.

\section{FUNDING INFORMATION}

This research is fully funded by the Institute for Research and Community Service through the Non-Tax State Revenue Fund (PNBP) Universitas Brawijaya in accordance with the Budget Implementation List (DIPA) University of Brawijaya №023.17.2.677512/2021.

\section{REFERENCES}

1. Chin-Hung, T. (1992). Studies on the Larval Culture of Varuna litterata.

2. Cumberlidge, N. (2016). Global diversity and conservation of freshwater crabs (Crustacea: Decapoda: Brachyura). In A Global Overview of the Conservation of Freshwater Decapod Crustaceans (pp. 1-22). Springer International Publishing.

3. Das, M., Kundu, J. K., \& Misra, K. K. (2015). Major lipid classes and their fatty acids in the flesh and hepatopancreas of an edible freshwater crab Varuna litterata (Fabricius 1798). International Journal of Research in Fisheries and Aquaculture, 5(1), 19-32.

4. Eprilurahman, R., \& Tejo Baskoro, W. (2015). Keanekaragaman Jenis Kepiting (Decapoda: Brachyura) di Sungai Opak, Daerah Istimewa Yogyakarta (Vol. 3, Issue 2).

5. Farias, N. E., Spivak, E. D., \& Luppi, T. A. (2017). Functional morphology of the female reproductive system of a crab with highly extensible seminal receptacles and extreme sperm storage capacity. Journal of Morphology, 278(7), 919-935.

6. Guimarães, M. P., Calado, T. C. dos S., \& de Barros, M.S.F. (2021). Gonad development in mature females of tidal spray crab Plagusia depressa (Brachyura: Plagusiidae). In Acta Zoologica (Vol. 102, Issue 3, pp. 227-236). Blackwell Publishing Ltd.

7. IUCN Red List. (2020). The IUCN Red List of Threatened Species.

8. Kali Mahapatra, B., Bhattacharya, S., Mahapatra, B., Bhattacharya, S., \& Pradhan, A. (2017). Some aspects of biology of Captive Maturation, Breeding and Culture of Some Indigenous Ornamental Fishes of Assam View project Network programme on "Ornamental fish breeding and culture" View project some aspects of biology of Chiti kankra, Varuna litterata (Fabricius, 1798) from Sundarbans, West Bengal, India. Journal of Entomology and Zoology Studies, 5(5), 178-183. https://www.researchgate.net/

9. Lakshmi Devi, P., \& Joseph, A. (2017). On the record of herring bow crab Varuna litterata (Fabricius, 1798) from Cochin Backwaters, India. In Indian Journal of Geo Marine Science (Vol. 46, Issue 05).

10. Lapolo, N., Utina, R., \& Baderan, D. W. K. (2018). Diversity and density of crabs in degraded mangrove area at tanjung panjang nature reserve in Gorontalo, Indonesia. Biodiversitas, 19(3), 1154-1159. https://doi.org/10.13057/biodiv/d190351.

11. Ngan Kee, N. (2006). The Systematics of the Crabs Of The Family Varunindae (Brachyura, Decapoda).

12. Otto Kiel, T. (2012). Reproduction Biology and Population Genetics of the alien Chinese mitten crab (Eriocheir sinensis) in Schleswig-Holstein.

13. Sal Moyano, M.P., Gavio, M.A., \& Maggi, M.D. (2011). Morphometric and gonad maturity of the spider crab Libinia spinosa (Crustacea: Brachyura: Majoidea: Epialtidae) in Argentina. J. of the Marine Biological Association of the United Kingdom, 91(4), 837-844.

14. Susilo, V. E., Wowor, D., Suratno, \& Abror, M. N. (2020). New record of Varuna litterata (Fabricius, 1798) from Meru Betiri National Park, East Java, Indonesia. IOP Conference Series: Earth and Environmental Science, 457(1). https://doi.org/10.1088/17551315/457/1/012016.

15. Yule, C. M., sen Yong, H., \& L Ng, P. K. (2012). 28. Crustacea Decapoda Brachyura Freshwater Biodiversity Observation Network (FW BON) View project neurogenetic View project Crustacea: Decapoda, Brachyura. https://www.researchgate.net/ 